JURNAL GIZI DAN DIETETIK INDONESIA

Vol. 4, No. 2, Mei 2016: 97-104
Tersedia online pada: http://ejournal.almaata.ac.id/index.php/IJND DOI : http://dx.doi.org/10.21927/ijnd.2016.4(2).97-104

\title{
Kebiasaan jajan dan pola makan serta hubungannya dengan status gizi anak usia sekolah di SD Sonosewu Bantul Yogyakarta
}

\author{
Snacking habits and diet with nutritional status of elementary school children in SD Sonosewu \\ Bantul Yogyakarta
}

Kurnia Noviani ${ }^{1}$, Effatul Afifah ${ }^{2}$, Dewi Astiti

\begin{abstract}
Background: Elementary school children are in the developmental age, thus need nutritions with good and proper quality and quantity. Nutrient needs can be fulfilled through eating habits. Snacking habit can also contribute to nutritional status in children if the snack consumed has good quality in term of the type and quantity.

Objectives: To understand the relationship between snacking habit and diet with nutritional status of elementary school children in SD Sonosewu Bantul Yogyakarta.

Methods: This study was an observational research with cross sectional approach. This study population was all students in SD Sonosewu Bantul Yogyakarta grades III, IV, V, that were 160 respondents. The sample used in this study was 65 people selected by using simple random sampling. The process of selecting a random sample was based on the random number table. The research instruments used were questionnaires, form of 24 -hour food recall for 1 day, bathroom scales, and microtoise. The collected data was analyzed by using a statistical test chi-square.

Results: Respondents who had frequent snacking habit with a normal nutritional status was 27 respondents (81\%), whereas those who had less frequent snacking habit with wasting nutritional status was 7 respondents (21.9\%). Respondents with a good diet (>80\% RDA) with wasting nutritional status was 9 respondents (75\%) and respondents who had bad diet with normal nutritional status was 34 respondents (66\%). Chi-Square analysis in the relationship between snacking habit and nutritional status obtained 0.781 $p$ value $(p>0.05)$ which mean that there was no statistically significant of relationship between snacking habits and child's nutritional status. Whereas Chi-Square analysis of diet and nutritional status showed a significant relationship with $0.008 p$ value $(p<0.05)$ means that there was a relationship between diet and nutritional status.
\end{abstract}

Conclusions: There was a relationship between diet and nutritional status of elementary school children, but there was no relationship between snacking habits and nutritional status of them.

KEYWORDS: snacking habit, diet, nutritional status, elementary school children

\begin{abstract}
ABSTRAK
Latar belakang: Anak usia sekolah dasar termasuk usia perkembangan sehingga membutuhkan nutrisi dengan kualitas maupun kuantitas yang baik dan benar. Kebutuhan gizi tersebut di antaranya dapat dipenuhi melalui kebiasaan makan. Pola jajan juga dapat memberikan kontribusi terhadap status gizi anak apabila jenis jajan yang dikonsumsi berkualitas dari segi jenis dan kandungan gizinya.

Tujuan: Tujuan dari penelitian ini adalah untuk mengetahui hubungan kebiasaan jajan dan pola makan dengan status gizi di SD Sonosewu Bantul Yogyakarta.

Metode: Penelitian ini merupakan penelitian observasional dengan rancangan cross sectional. Populasi dalam penelitian ini adalah seluruh siswa dari kelas III, IV, V yang berjumlah 160 siswa di SD Sonosewu
\end{abstract}

\footnotetext{
1,2Prodi S1 IImu Gizi, Universitas Alma Ata Yogyakarta, Jl. Ring Road Barat Daya No.1, Yogyakarta, e-mail: kurnianoviani@yahoo.com
} 
Bantul Yogyakarta. Sampel dalam penelitian ini berjumlah 65 yang diambil dengan teknik simple random sampling. Proses memilih sejumlah sampel secara random berdasarkan tabel bilangan random. Instrumen penelitian yang digunakan yaitu kuesioner, formulir food recall 24 jam selama 1 hari, timbangan injak, dan microtois. Data yang telah dikumpulkan kemudian dianalisis menggunakan uji statistic chi-square.

Hasil: Responden yang memiliki kebiasaan jajan sering dengan status gizi normal yaitu sebanyak 27 responden (81\%), dan yang tidak sering jajan dengan status gizi kurus berjumlah 7 responden (21,9\%). Responden dengan pola makan yang baik >80\% AKG dengan status gizi kurus sebesar 9 responden (75\%) dan responden yang memiliki pola makan tidak baik dengan status gizi normal sebesar 34 responden (66\%). Hasil analisis chi-square hubungan kebiasaan jajan dengan status gizi diperoleh $p$ 0,781 $(p>0,05)$ yang berarti bahwa tidak ada hubungan antara kebiasaan jajan dengan status gizi. Hasil analisis ChiSquare hubungan pola makan dengan status gizi diperoleh $p 0,008(p<0,05)$ yang berarti bahwa ada hubungan antara pola makan dengan status gizi.

Kesimpulan: Tidak ada hubungan kebiasaan jajan dengan status gizi di SD Sonosewu Bantul Yogyakarta. Ada hubungan pola makan dengan status gizi di SD Sonosewu Bantul Yogyakarta.

KATA KUNCI: kebiasaan jajan, pola makan, status gizi, anak sekolah dasar

\section{PENDAHULUAN}

Anak usia sekolah adalah investasi bangsa, karena anak usia tersebut merupakan generasi penerus bangsa. Tumbuh berkembangnya anak usia sekolah yang optimal tergantung pemberian nutrisi atau asupan zat gizi pada anak tidak selalu dapat dilaksanakan dengan sempurna. Banyak sekali masalah yang ditimbulkan dalam pemberian makanan yang tidak benar dan menyimpang. Penyimpangan ini mengakibatkan gangguan pada banyak organ dan sistem tubuh anak (1). Salah satu cara untuk memperoleh status kesehatan dan gizi yang baik yaitu dengan membiasakan sarapan pagi. Sarapan pagi merupakan waktu makan yang sangat penting (2).

Menurut data riset kesehatan dasar (Riskesdas) 2013, prevalensi nasional anak usia sekolah kurus (menurut IMT/U) adalah 11,2\% terdiri dari 4,0\% sangat kurus dan $7,2 \%$ kurus. Prevalensi anak usia sekolah gemuk adalah $18,8 \%$, terdiri dari gemuk $10,8 \%$ dan sangat gemuk (obesitas) $8,8 \%$. Pada wilayah DI Yogyakarta, prevalensi anak dengan kategori gemuk sebesar $9,1 \%$, kategori sangat gemuk $6,9 \%$, kategori normal $76,5 \%$, kategori kurus $5,8 \%$, dan kategori sangat kurus $1,7 \%(3)$.

Kebiasaan jajan anak sekolah di Yogyakarta cenderung meningkat dan anak memilih konsumsi jajan yang kurang sehat. Kebiasaan jajan cenderung menjadi bagian budaya dari satu keluarga. Makanan jajanan di luar/di sekolah seringkali tidak memperhatikan mutu gizi, kebersihan, dan keamanan bahan pangan. Tidak sedikit masalah yang timbul akibat orang tua kurang peduli terhadap makanan yang dikonsumsi anak di sekolah. Makanan yang tidak aman dan tidak bergizi menimbulkan penyakit, seperti diare bahkan kanker dan dapat mengakibatkan tidak tercapainya angka kecukupan gizi. Penelitian ini bertujuan untuk membuktikan hubungan antara kebiasaan jajan dan pola makan anak usia sekolah dengan status gizi di SD Sonosewu Bantul Yogyakarta.

\section{BAHAN DAN METODE}

Jenis penelitian yang digunakan adalah analitik observasional dengan rancangan cross sectional. Penelitian ini dilaksanakan di SD Sonosewu Bantul Yogyakarta pada bulan Februari 2016. Populasi dalam penelitian ini adalah seluruh siswa dari kelas III, IV, dan V yang berjumlah 160 siswa di SD Sonosewu Bantul Yogyakarta. Besar sampel minimal dengan menggunakan rumus Lemeshow adalah 61 dan didapatkan jumlah sampel sebesar 65 siswa. Pengambilan sampel dilakukan secara simple random sampling berdasarkan tabel bilangan random. Instrumen penelitian yang digunakan yaitu kuesioner terstruktur yang telah dilakukan uji coba pada 30 orang siswa SD Kasihan Yogyakarta, formulir food recall 24 jam, timbangan injak, dan microtoise. Penelitian ini juga telah memperoleh persetujuan etik dari Komite etik Universitas Alma Ata Yogyakarta. 


\section{HASIL}

\section{Karakteristik responden anak}

Dari Tabel 1 dapat dilihat bahwa dari 65 responden yang diteliti, persentase siswa berjenis kelamin perempuan sebanyak 35 responden $(53,8 \%)$ dan sisanya laki-laki sebanyak 30 responden $(46,2 \%)$. Hal ini menunjukkan bahwa proporsi jumlah perempuan lebih besar daripada proporsi jumlah lakilaki. Kategori umur paling banyak dalam penelitian ini yaitu 10 tahun berjumlah 30 siswa $(46,2 \%)$ dan yang paling sedikit yaitu umur 9 tahun berjumlah 12 siswa $(18,5 \%)$. Pemilihan responden berdasarkan usia adalah usia 9-11 tahun dengan memperhatikan kisaran usia siswa kelas III, IV, dan V sekolah dasar. Jumlah uang saku siswa yang paling banyak adalah dalam kategori $<R p$ 5.000,-/hari yaitu sebanyak 46 responden $(70,8 \%)$, dan yang paling sedikit $>\mathrm{Rp}$ 10.000,- yaitu 9 responden (13,8\%). Pengukuran status gizi (IMT/U) responden dikategorikan menjadi 3 kelompok dan sebagian besar responden $(78,5 \%)$ mempunyai status gizi normal. Frekuensi makanan jajanan lebih banyak termasuk dalam kategori tidak sering yaitu 33 siswa $(50,8 \%)$.

Tabel 1. Distribusi subjek penelitian berdasarkan jenis kelamin, umur, uang saku, status gizi, dan kebiasaan jajan

\begin{tabular}{|c|c|c|}
\hline Variabel & $\mathbf{n}$ & $\%$ \\
\hline \multicolumn{3}{|l|}{ Jenis kelamin } \\
\hline Laki-laki & 30 & 46,2 \\
\hline Perempuan & 35 & 53,8 \\
\hline Total & 65 & 100 \\
\hline \multicolumn{3}{|l|}{ Umur } \\
\hline 9 tahun & 12 & 18,5 \\
\hline 10 tahun & 30 & 46,2 \\
\hline 11 tahun & 23 & 35,4 \\
\hline Total & 65 & 100 \\
\hline \multicolumn{3}{|l|}{ Uang saku } \\
\hline$<\operatorname{Rp} 5.000$ & 46 & 70,8 \\
\hline Rp 5.000-Rp 10.000 & 10 & 15,4 \\
\hline$>\operatorname{Rp} 10.000$ & 9 & 13,8 \\
\hline Total & 65 & 100 \\
\hline \multicolumn{3}{|l|}{ Status gizi } \\
\hline Normal & 51 & 78,5 \\
\hline Gizi kurang & 12 & 18,5 \\
\hline Gizi lebih & 2 & 3,1 \\
\hline Total & 65 & 100 \\
\hline \multicolumn{3}{|l|}{ Kebiasaan jajan } \\
\hline Sering & 32 & 49,2 \\
\hline Tidak sering & 33 & 50,8 \\
\hline Total & 65 & 100 \\
\hline
\end{tabular}

\section{Karakteristik responden ayah dan ibu}

Hasil penelitian ini menunjukkan bahwa pendidikan akhir ayah responden memiliki persentase tertinggi pada pendidikan tamat SMA/ sederajat sebanyak 26 responden $(40 \%)$ dan untuk pendidikan terakhir ibu dengan jenjang paling rendah adalah tamat SMP/sederajat sebanyak 21 responden (32,3\%) (Tabel 2).

Tabel 2. Distribusi subjek penelitian berdasarkan pendidikan, pekerjaan dan penghasilan ayah dan ibu

\begin{tabular}{|c|c|c|}
\hline Variabel & $\mathbf{n}$ & $\%$ \\
\hline \multicolumn{3}{|l|}{ Pendidikan ayah } \\
\hline Tidak tamat SD & 3 & 4,6 \\
\hline Tamat SD/sederajat & 8 & 12,3 \\
\hline Tamat SMP/sederajat & 16 & 24,6 \\
\hline Tamat SMA/sederajat & 26 & 40,0 \\
\hline Tamat Diploma & 12 & 18,5 \\
\hline Total & 65 & 100 \\
\hline \multicolumn{3}{|l|}{ Pekerjaan ayah } \\
\hline Petani/peternak/nelayan & 1 & 1,5 \\
\hline Buruh/buruh tani & 4 & 36,9 \\
\hline Karyawan swasta & 12 & 18,5 \\
\hline Pegawai negeri/TNI/POLRI & 2 & 3,1 \\
\hline Wiraswasta & 19 & 29,2 \\
\hline Tidak bekerja & 3 & 4,6 \\
\hline Lain-lain & 4 & 6,2 \\
\hline Total & 65 & 100 \\
\hline \multicolumn{3}{|l|}{ Pendapatan ayah } \\
\hline Rp 0 s.d. Rp 500.000,- & 15 & 23,1 \\
\hline Rp 600.000,- s.d. Rp 1.000.000,-- & 28 & 43 \\
\hline Rp 1.100.000,- s.d. Rp 2.000.000,- & 12 & 18,5 \\
\hline$>\operatorname{Rp} 2.000 .000,-$ & 10 & 15,4 \\
\hline Total & 65 & 100 \\
\hline \multicolumn{3}{|l|}{ Pendidikan ibu } \\
\hline Tidak tamat SD & 5 & 7,7 \\
\hline Tamat SD/sederajat & 7 & 10,7 \\
\hline Tamat SMP/sederajat & 21 & 32,3 \\
\hline Tamat SMA/sederajat & 20 & 30,8 \\
\hline Tamat Diploma & 12 & 18,5 \\
\hline Total & 65 & 100 \\
\hline \multicolumn{3}{|l|}{ Pekerjaan ibu } \\
\hline Petani/peternak & 1 & 1,5 \\
\hline Buruh/buruh tani & 6 & 9,2 \\
\hline Karyawan swasta & 6 & 9,2 \\
\hline Wiraswasta & 11 & 16,9 \\
\hline Ibu rumah tangga/tidak bekerja & 37 & 56,9 \\
\hline Lain-lain & 4 & 6,2 \\
\hline Total & 65 & 100 \\
\hline \multicolumn{3}{|l|}{ Pendapatan ibu } \\
\hline Rp 0 s.d. Rp 500.000,- & 50 & 76,9 \\
\hline Rp 600.000,- s.d. Rp 1.000.000,-- & 6 & 9,2 \\
\hline Rp 1.100.000,- s.d. Rp 2.000.000,- & 7 & 10,8 \\
\hline$>$ Rp 2.000.000,- & 2 & 3,1 \\
\hline Total & 65 & 100 \\
\hline
\end{tabular}




\section{Pola makan}

Jenis makanan. Data konsumsi makanan menunjukkan bahwa seluruh responden mengonsumsi makanan pokok dan sebagian besar mengonsumsi lauk nabati, hewani, dan sayur, namun hanya sebagian kecil responden yang mengonsumsi buah (2\%) (Tabel 3 ).

Tabel 3. Distribusi responden berdasarkan kategori jenis makanan dalam sehari

\begin{tabular}{lcc}
\hline \multicolumn{1}{c}{ Jenis makanan } & $\mathbf{n}$ & $\mathbf{\%}$ \\
\hline Makanan pokok & 65 & 100 \\
Lauk hewani & 59 & 90,8 \\
Lauk nabati & 40 & 61,5 \\
Sayur & 47 & 72,3 \\
Buah & 13 & 2 \\
Susu & 31 & 47,7 \\
\hline
\end{tabular}

Jumlah makanan. Berdasarkan hasil penelitian yang ditampilkan dalam Tabel 4 menunjukkan bahwa sebagian besar $(56,9 \%)$ pola makan dari responden dikategorikan dalam pola makan kurang baik (hanya memenuhi $<85 \%$ AKG anak usia sekolah) dan kategori pola makan baik ( $\geq$ $80 \%$ AKG) sebanyak 28 responden (43\%).

Hubungan kebiasaan jajan dengan status gizi anak. Berdasarkan hasil analisis Chi-Square untuk variabel kebiasaan jajan dan status gizi siswa diperoleh $p$ value $0,781(p>0,05)$. Hal ini berarti hipotesis null gagal ditolak yang artinya tidak ada hubungan yang signifikan antara kebiasaan jajan dengan status gizi pada siswa SD Sonosewu Bantul Yogyakarta (Tabel 5).
Tabel 4. Distribusi berdasarkan pola makan

\begin{tabular}{lcc}
\hline \multicolumn{1}{c}{ Pola makan } & n & \% \\
\hline Baik $\geq 80 \%$ AKG & 28 & 43 \\
Kurang $<80 \%$ AKG & 37 & 56,9 \\
Total & 65 & 100 \\
\hline
\end{tabular}

Hubungan pola makan berdasarkan jumlah dengan status gizi anak. Berdasarkan hasil analisis Chi-Square terhadap variabel pola makan berdasarkan jumlah dengan status gizi diperoleh $p$ value sebesar $0,008(p<0,05)$. Hal ini berarti hipotesis null ditolak yang artinya ada hubungan signifikan antara pola makan berdasarkan jumlah dengan status gizi pada siswa SD Sonosewu Bantul Yogyakarta (Tabel 6).

\section{Pola makan berdasarkan keragaman jenis dengan status gizi anak.}

Tabel 7 menunjukkan bahwa pola makan responden termasuk dalam kategori pola makan baik dengan status gizi normal sebanyak 30 responden $(60 \%)$. Hasil penelitian membuktikan bahwa tidak ada hubungan antara pola makan berdasarkan keragaman jenis dengan status gizi $(p>0,05)$.

\section{BAHASAN}

Karakteristik responden dalam penelitian ini sejalan dengan penelitian lain yaitu proporsi anak perempuan lebih besar $(62 \%)$ daripada proporsi anak laki-laki (38\%) (4). Hal ini dapat dipengaruhi

Tabel 5. Hubungan kebiasaan jajan dengan status gizi anak

\begin{tabular}{lccccc}
\hline \multirow{2}{*}{ Kebiasaan jajan } & \multicolumn{3}{c}{ Status gizi } & \multirow{2}{*}{ Total } & \multirow{2}{*}{$\boldsymbol{p}$} \\
\cline { 2 - 5 } & Kurang & Normal & Lebih & & \\
\cline { 2 - 5 } & $\mathbf{n}(\%)$ & $\mathbf{n ~ ( \% )}$ & $\mathbf{n ~ ( \% )}$ & $\mathbf{n ~ ( \% )}$ & \\
\hline Sering ( $\leq 2$ kali sehari) & $7(21,9)$ & $24(75)$ & $1(3,1)$ & $32(100)$ & 0,781 \\
Tidak sering (>2 kali sehari) & $5(15,2)$ & $27(81)$ & $1(3)$ & $33(100)$ & \\
\hline
\end{tabular}

Tabel 6. Hubungan pola makan berdasarkan jenis dengan status gizi

\begin{tabular}{lccccc}
\hline \multirow{2}{*}{ Pola makan } & \multicolumn{3}{c}{ Status gizi } & \multirow{2}{*}{ Total } & \multirow{2}{*}{$\boldsymbol{p}$} \\
\cline { 2 - 4 } & Kurus & Normal & Lebih & & \\
\cline { 2 - 4 } & $\mathbf{n ~ ( \% )}$ & $\mathbf{n ~ ( \% )}$ & $\mathbf{n ~ ( \% )}$ & & 0,008 \\
\hline Baik $\geq 80 \%$ AKG & $9(32 \%)$ & $17(60 \%)$ & $2(7,1 \%)$ & $28(100 \%)$ & 0 \\
Kurang $<80 \%$ AKG & $3(8,1 \%)$ & $34(91 \%)$ & $0(0 \%)$ & $37(100 \%)$ & \\
\hline
\end{tabular}


Tabel 7. Hubungan pola makan (jumlah) dengan status gizi

\begin{tabular}{|c|c|c|c|c|c|}
\hline \multirow{3}{*}{ Pola makan } & \multicolumn{3}{|c|}{ Status gizi } & \multirow{3}{*}{ Total } & \multirow{3}{*}{$p$} \\
\hline & Kurus & Normal & Lebih & & \\
\hline & n (\%) & n (\%) & n (\%) & & \\
\hline Baik & $6(16 \%)$ & $30(60 \%)$ & $1(2,7 \%)$ & $37(100 \%)$ & 0,63 \\
\hline Sedang & $3(15,7 \%)$ & $15(78 \%)$ & $1(5,2 \%)$ & $19(100 \%)$ & \\
\hline Kurang & $3(37,5 \%)$ & $5(62,5 \%)$ & $0(0 \%)$ & $8(100 \%)$ & \\
\hline
\end{tabular}

Keterangan:

Baik (> 4 jenis terdiri dari makanan pokok, lauk pauk, sayuran, buah-buahan, dan susu)

Sedang ( 3 jenis terdiri dari makanan pokok dan lauk pauk dan sayuran)

Tidak baik (<3 jenis terdiri dari makanan pokok dan lauk pauk/sayuran/ buah-buahan)

oleh jumlah anak perempuan yang memang lebih besar dibandingkan anak laki-laki (Tabel 1). Kategori usia anak dalam penelitian ini merupakan usia kelompok rentan gizi. Pada umumnya, kelompok ini berhubungan dengan proses pertumbuhan yang relatif pesat dan memerlukan zat-zat gizi dalam jumlah relatif besar (5).

Penelitian pada siswa sekolah dasar di Kabupaten Bogor menunjukkan bahwa $46 \%$ siswa mengalokasikan uang saku yang diberikan oleh orang tuanya untuk membeli jajan. Berdasarkan sebaran uang saku contoh, maka uang saku dalam penelitian ini dibagi menjadi tiga kategori, yaitu rendah (<Rp 5.000,-), sedang (Rp 5.000,- s.d. Rp $10.000,-)$, dan tinggi ( $\geq \operatorname{Rp} 10.000,-)(6)$.

Pendidikan orang tua akan mempengaruhi status pekerjaan dan penghasilan keluarga. Data ketenagakerjaan hasil Sensus Penduduk tahun 2010 menunjukkan tingkat pengangguran terbuka (TPT) tertinggi berada pada pendidikan SMU/SMK yang mencapai 7,4 persen, sedangkan TPT untuk tingkat SLTP hanya 5,3 persen, dan SD ke bawah hanya 1,9 persen. Hal ini menunjukkan bahwa tingkat pendidikan berpengaruh negatif terhadap status pekerjaan. Semakin tinggi tingkat pendidikan, semakin kecil kesempatan untuk mendapatkan pekerjaan.

Salah satu unsur penting yang dapat mempengaruhi keadaan gizi keluarga adalah pendidikan orang tua terutama ibu. Pendidikan ibu adalah faktor yang sangat penting dalam proses tumbuh kembang anak. Ibu yang memiliki tingkat pendidikan yang tinggi akan lebih mudah dalam menerima pesan dan informasi gizi dan kesehatan anak (7). Pendidikan juga diperlukan untuk meningkatkan kesejahteraan sosial seseorang dan keluarganya.

Tingkat pendidikan seringkali digunakan untuk mengukur status sosial seseorang. Namun demikian, tidak berarti bahwa pendidikan tinggi dengan sendirinya menjamin kedudukan sosial yang tinggi (8). Pendidikan orang tua yang dilihat dalam penelitian ini merupakan jenjang atau tingkat pendidikan formal terakhir yang diikuti oleh orang tua responden (Tabel 2).

Hasil penelitian ini membuktikan tidak ada hubungan antara kebiasaan jajan dan status gizi pada siswa SD Sonosewu Bantul Yogyakarta (Tabel 5). Hal ini mungkin terjadi karena dalam penelitian ini hanya melihat frekuensi jajan saja tanpa memperhatikan kualitas dan kuantitas makanan jajanan tersebut. Namun demikian, sebuah teori menyatakan bahwa kebiasaan jajan dapat meningkatkan asupan energi sehingga berlebih dibandingkan dengan energi yang keluar (energy expenditure) dan kebiasaan jajan dapat meningkatkan total energi yang berasal dari asupan lemak sehingga memicu kenaikan berat badan bila tidak sesuai dengan energi yang keluar (9).

Kebiasaan sarapan juga dapat mempengaruhi status gizi anak di samping kebiasaan jajan. Pengaruh sarapan terhadap status gizi yaitu melalui pemenuhan kebutuhan zat gizi karena sarapan dapat memberikan sumbangan zat gizi per harinya. Anak yang tidak sarapan akan berisiko mengalami defisiensi zat gizi. Jika hal ini berlangsung lama akan berpengaruh terhadap status gizinya. Sarapan yang baik akan memberikan sumbangan energi 
sebanyak $20 \%$. Status gizi yang baik atau optimal akan tercapai apabila tubuh memperoleh cukup zat gizi yang digunakan secara efisien, sehingga memungkinkan pertumbuhan fisik, pertumbuhan otak, kemampuan kerja otak. Seorang anak yang sehat dan normal akan tumbuh sesuai dengan potensi genetik yang dimilikinya, tetapi pertumbuhan ini juga akan dipengaruhi oleh asupan gizi yang dikonsumsi dalam bentuk makanan. Cadangan energi yang rendah dan tinggi lemak akan berdampak pada penurunan produktivitas dan prestasi belajar pada anak sekolah sebagai akibat kekurangan dan kelebihan zat gizi. Kekurangan atau kelebihan zat gizi akan mempengaruhi status gizi anak (10).

Hasil penelitian ini mempunyai kesamaan hasil dengan penelitian yang dilakukan di Bogor yang menunjukkan bahwa $70 \%$ siswa SD 1 Kota Bogor mempunyai kebiasaan jajan (7). Demikian pula penelitian di SDN Palasari 02 Bogor yang menyatakan bahwa makanan jajanan tidak berpengaruh terhadap status gizi, namun mampu meningkatkan nilai $Z$-score (11). Namun penelitian lain menunjukkan hasil yang berbeda yaitu sejumlah $63,7 \%$ siswa SD N Koroulon 1 Ngemplak Sleman tidak mempunyai kebiasaan jajan (12). Perbedaan hasil ini dapat disebabkan oleh berbagai faktor di antaranya pengaruh dari orang tua, budaya/adat, pengaruh teman sebaya, harga, merek, pengetahuan, sikap. Pada penelitian ini subjek penelitiannya adalah anak SD Negeri Kledokan Depok Sleman Yogyakarta yang dapat dikatakan berada di wilayah perkotaan, sedangkan penelitian sebelumnya berada di wilayah desa. Hal ini menyebabkan adanya perbedaan perilaku jajan anak. Anak di wilayah kota lebih cenderung senang untuk jajan yang dipengaruhi oleh faktor lingkungan serta sosial ekonomi orang tua.

Pola makan yang baik pada anak salah satunya dapat disebabkan orang tua telah mengajarkan kepada anak tentang kebiasaan makan yang baik, yaitu sebagai contoh sarapan pagi sebelum berangkat ke sekolah. Anak usia sekolah dapat mengikuti pola makan keluarga serta bentuk dan kebutuhannya harus diatur. Orang tua cenderung mengatur pola makan anaknya berdasarkan jenis dan jumlah makanan yang dimakan dan memperhatikan jadwal makan. Responden yang memiliki pola makan kurang baik karena orang tua tidak membudayakan disiplin makan pada anak, mereka cenderung menuruti kemauan anak tanpa memperhatikan nilai gizi yang anak mereka makan.

Hasil penelitian ini yang menunjukkan tidak ada hubungan pola makan berdasarkan jumlah dengan status gizi (Tabel 7). Berbeda dengan penelitian yang dilakukan Suhariati yang membuktikan ada hubungan antara pola makan dengan status gizi anak di Desa Jerukwangi Kecamatan Kandangan Kabupaten Kediri $(p<0,05)$. Pola makan sangat mempengaruhi keadaan gizi seseorang. Pola makan yang baik dapat meningkatkan status gizi. Keadaan gizi kurang terjadi karena tubuh kekurangan satu atau beberapa jenis zat gizi yang dibutuhkan seperti jumlah zat gizi yang dikonsumsi kurang, mutunya rendah, dan frekuensi makan kurang. Penelitian di Mapanget yang mengatakan bahwa hubungan pola makan dengan status gizi sangat kuat (13). Asupan gizi seimbang dari makanan memegang peranan penting dalam proses pertumbuhan anak dibarengi dengan pola makan yang baik dan teratur yang perlu diperkenalkan sejak dini, antara lain dengan perkenalan jam-jam makan dan variasi makanan dapat membantu mengkoordinasikan kebutuhan akan pola makan sehat pada anak.

Penelitian ini tidak menunjukkan adanya hubungan antara pola makan berdasarkan keragaman jenis dengan status gizi siswa (Tabel 6). Hal ini mungkin disebabkan selain jenis bahan makanan, kuantitas atau jumlah konsumsi dari setiap bahan makanan yang berdampak pada jumlah asupan kalori akan memiliki dampak yang lebih nyata terhadap status gizi anak. Komposisi zat gizi setiap jenis makanan memiliki keunggulan dan kelemahan. Beberapa makanan mengandung tinggi karbohidrat tetapi kurang vitamin dan mineral, sehingga konsumsi makanan sehari-hari yang kurang beraneka ragam dan jumlah yang tidak seimbang, maka akan timbul ketidakseimbangan antara masukan dengan kebutuhan zat gizi yang diperlukan untuk hidup dan pruduktif. Dengan kata lain, untuk 
mencapai masukan zat gizi yang seimbang tidak mungkin dipenuhi hanya oleh satu jenis bahan makanan, melainkan harus terdiri dari aneka ragam makanan. Pemenuhan gizi seimbang bukanlah hal mudah bagi anak, karena aktivitas anak yang banyak. Padahal kebutuhan gizi yang terpenuhi dengan baik akan membuat orang lebih memikili perhatian dan kemampuan untuk belajar lebih mudah. Hal ini menunjukkan bahwa orang tua harus memperhatikan pola makan dari aspek jenis makanan yang dikonsumsi oleh anaknya.

\section{KESIMPULAN DAN SARAN}

Sebanyak $53,8 \%$ siswa SD Sonosewu Bantul Yogyakarta yang diteliti berjenis kelamin perempuan, memiliki uang jajan $<$ Rp 5.000,- per hari, lebih dari $40 \%$ berusia 10 tahun. Sebanyak $36,9 \%$ pendidikan orang tua siswa adalah lulusan SMA, dengan jenis pekerjaan terbesar buruh/ buruh tani pada ayah sedangkan pada ibu tidak bekerja $56,9 \%$ dan sebanyak $43 \%$ pendapatan orang tua Rp 600.000,- s.d. Rp 1.000.000,-Sebanyak $81 \%$ siswa SD Sonosewu Bantul Yogyakarta memiliki perilaku jajan tidak sering dan $33 \%$ siswa mempunyai pola makan yang baik dan mempunyai status gizi yang baik. Diketahui tidak ada hubungan yang bermakna antara kebiasaan jajan dengan status gizi, demikian pula antara pola makan berdasarkan jenis dengan status gizi. Antara pola makan berdasarkan jumlah berhubungan dengan status gizi.

Bagi sekolah, disarankan untuk mengadakan program pemantauan status gizi dan kesehatan secara rutin serta memberikan penyuluhan atau edukasi terkait konsumsi makanan yang bergizi seimbang dalam mata pelajaran penjaskes. Selain itu, menyeleksi dan mengedukasi para pedagang makanan di kantin dan sekitar sekolah mengenai higiene dan sanitasi makanan serta untuk menyediakan makanan jajanan yang bergizi seimbang sehingga turut berpartisipasi terhadap perbaikan status gizi para siswa. Bagi siswa, sebaiknya memilih makanan yang bersih dan sehat serta bergizi seimbang sesuai dengan kebutuhan. Bagi orang tua, diharapkan untuk selalu memperhatikan dan menyediakan pemenuhan kebutuhan gizi anak yang sesuai dengan umur anak tersebut.

\section{RUJUKAN}

1. Judarwanto, Widodo. Perilaku makan anak sekolah. 2008.

2. Isdaryani. Skripsi hubungan asupan energi, protein, status gizi dan prestasi belajar anak Sekolah Dasar Arjowinangun 1 Pacitan Yogyakarta. Universitas Gadjah Mada; 2007.

3. Badan Penelitian dan Pengembangan Kesehatan Republik Indonesia. Riset kesehatan dasar 2013. Jakarta: Badan Penelitian dan Pengembangan Kesehatan RI; 2013.

4. Nainggolan J. Hubungan antara pengetahuan dan sikap ibu dengan status gizi balita di Wilayah Kera Puskesmas Rajabasa Indah Kelurahan Rajabasa Raya Bandar Lampung [Internet]. 2011 [cited 2016 May 8]. Available from: http:// jukeunila.com/wp-content/uploads/2016/03/5Julita-Nainggolan.pdf

5. Soediaoetama, Djaelani A. IImu gizi untuk mahasiswa dan profesi. Jakarta: Penerbit Dian Rakyat; 2008.

6. Sugiyono. Metode penelitian bisnis. Bandung: Alfa Beta; 2011.

7. Rahmawati. Pengaruh asimetri informasi terhadap praktik managemen laba pada perusahaan public yang terdaftar di bursa efek [Internet]. 2006 [cited 2016 Jun 20]. Available from: Jakarta. http://Muhariefendi.files.pdf

8. Puspita F. Analisis faktor-faktor yang mempengaruhi kebijakan difident payout ratio (studi kasus pada perusahaan yang terdaftar di Bursa Efek Indonesia Periode 2005-2007). Universitas Diponegoro; 2009.

9. Keast, Nickhar, O'Neil C. Snacking is assotiatesd with reduced risk of overweight and reduced abnormal obesity in adolescence: national health and nutrition excumination survey (NHANES). Am J Nutr. 2010;92:428-35.

10. Thompsom J, Strickland A, Gamble E. Crafting and executing strategy, seventeenth edition. New York: Mc Graw-hill//rwin. Inc. New; 2010. 
11. Candra A, Setiawan B, Damanik R. Pengaruh pemberian makanan jajanan, pendidikan gizi, dan suplementasi besi terhadap status gizi, pengetahuan gizi, dan status anemia pada siswa sekolah dasar. JGIZIPANGAN. 2013;8(2):103-8.

12. Palulun J. Hubungan kebiasaan sarapan pagi dengan status gizi anak Sekolah dasar di SD
Negeri Koroulon 1 Ngemplak Sleman Yogyakarta. Universitas Gadjah Mada; 2006.

13. Tella A. Hubungan pola makan dengan status gizi pada balita di Wilayah Kerja Puskesmas Paniki Kecamatan Mapenget Manado. Universitas Samratulangi; 2012. 